RRH: MacPherson et al $•$ Austral migrant shifts trophic niche during molt

\title{
Evidence of a trophic niche shift in an omnivorous migratory bird in South America: A comparison of stable isotope signatures in feathers between migratory and sedentary subspecies of Tyrannus savana
}

\section{Maggie P. MacPherson, ${ }^{1,2, *}$ Alex E. Jahn, ${ }^{3,4}$ Justin DeFreitas, ${ }^{5}$ Kooldeep Looknauth, ${ }^{5}$ Asaph Wilson, ${ }^{5}$ Leon Baird, ${ }^{5}$ Kayla DeFreitas, ${ }^{5}$ Susan Chiasson, ${ }^{2,6}$ Caz Taylor $^{2}$}

${ }^{1}$ Louisiana State University Museum of Natural Science, Louisiana State University, Baton Rouge, LA, USA

${ }^{2}$ Department of Ecology and Evolutionary Biology, Tulane University, New Orleans, LA, USA

${ }^{3}$ Environmental Resilience Institute, Indiana University, Bloomington, IN, USA

${ }^{4}$ Departamento de Zoologia, Universidade Estadual Paulista, Av. 24a No. 1515, Rio Claro, Brazil

${ }^{5}$ South Rupununi Conservation Society, Wichabai Ranch, South Rupununi, Region 9, Guyana

${ }^{6}$ Biology Department, Loyola University, New Orleans, LA, USA

*Corresponding author: maggie.macpherson@gmail.com

Abstract - Understanding how diet and life history strategies interact is important for exploring constraints of available nutrition on energetically expensive life history events in wild animals (i.e., reproduction, annual migration, or molt). Previous research on migratory birds breeding in the Northern Hemisphere has demonstrated trophic niche shifts from invertebrates to fruit in order to fuel spring migration. We examined whether a trophic niche switch occurred in a Neotropical austral migrant bird, Tyrannus savana savana prior to spring migration by measuring stable nitrogen isotopes in feathers. We found that the austral migrant $T$. s. savana did appear to shift in diet from a higher to lower trophic level (consistent in pattern with a shift from a higher to lower ratio of invertebrates to fruit) but the shift occurred earlier than expected if it was preparation for migration. A sympatric sedentary subspecies (T. s. monachus) appeared to forage only at the lower trophic level during their annual molt and that show no evidence of a trophic niche shift. The timing of the trophic niche shift leads us to conclude that a higher trophic level diet early in molt is not related to preparation for spring migration in this species but suggest that it may be related to seasonal changes in food availability as the wet season concludes. A remaining challenge for understanding the ecological consequences of trophic 
niche shifts is to find ways to empirically measure trade-offs between different diets across energetically expensive life history activities and compare these between taxa with differing life history strategies.

Key Words: flycatcher, migratory ecology, stable nitrogen isotope analysis, Tyrannus savana.

One of the most critical parts of the annual cycle of migratory birds is the preparation for and successful completion of spring migration, because properly timing arrival on the breeding grounds is a key determinant of successful reproduction (Smith \& Moore, 2005; Tomotani, Caglar, de la Hera, Mateman, \& Visser, 2017; Visser, Holleman, \& Gienapp, 2006). One of the most important components of the preparation for migration is fattening, because migration is an intense period of fasting in which energetic balance is maintained by drawing on previously deposited fat stores (Battley et al., 2001), which represent the main fuel for migration of migratory birds such as passerines and shorebirds (Klaassen \& Biebach, 1994; Klaassen, Lindström, \& Ziljstra, 1997; Lindström \& Piersma, 1993) because it is more energy dense than other potential fuels, such as carbohydrates and protein (Newsholme \& Leech, 1985; Pond, 1981). However, almost all research into how birds prepare for migration is based on species that breed in the Northern Hemisphere (primarily in North America and Europe), such that we know much less about this process in birds that migrate wholly within the Southern Hemisphere (Jahn et al., 2020; Tuero, Jahn, \& MacPherson, 2019).

To help address this gap, we studied a common migratory bird in the Neotropical austral migrant system, in which birds breed at south-temperate latitudes of South America and overwinter closer to the Equator (reviewed by Chesser, 1994; Jahn et al., 2020). We compared 
the diets of migratory and sedentary sister taxa (Tyrannus savana savana - migratory, and T. s. monachus - sedentary) during the period when they are seasonally sympatric in northern South America (Gómez-Bahamón et al., 2020). During this period of sympatry, sedentary T. s. monachus are breeding and beginning their feather molt, whereas the migratory $T$. s. savana are overwintering and molting feathers prior to initiating spring migration to their breeding grounds in southern portions of the continent (Figs. 1 and 2). Such a comparative framework has been successfully employed to test hypotheses that explain differences between migratory and nonmigratory (sedentary) bird taxa in their coloration (Fitzpatrick et al., 2004), vocal complexity (Najar \& Benedict, 2019; Nelson, Marler, \& Morton, 1996), breeding phenology (Kimmitt, Sinkiewicz, \& Ketterson, 2020), and fitness (Buchan, Gilroy, Catry, \& Franco, 2020), as well as a history of linking morphology with diet or foraging guild (Tellería, Blázquez, De La Hera, \& Pérez-Tris, 2013; Neto et al., 2013).

We hypothesized that the migratory subspecies would switch from a diet of more invertebrates to a diet of more fruit in preparation for spring migration, as observed in their Northern Hemisphere counterparts, whereas the resident subspecies would not exhibit such a shift. Both subspecies molt simultaneously prior to the spring migration of the migratory $T . s$. savana, so we predict that if $T$. s. savana shifts trophic levels, we would see: 1) significantly lower $\delta^{15} \mathrm{~N}$ values of the migratory subspecies' feathers grown at the end of molt relative to the feathers grown at the beginning of molt, because tissues become more enriched with the heavier nitrogen isotope when consuming foods at higher trophic levels (Hobson \& Bairlein, 2003; McKinnon, Kyser, \& Stutchbury, 2017), and 2) consistently higher $\delta^{15} \mathrm{~N}$ values in feathers grown across the molt schedule of the sedentary subspecies T. s. monachus, as compared to the migratory subspecies. There is no known evidence of competition for food resources between 
these subspecies, so we did not expect to find significant differences between $\delta^{15} \mathrm{~N}$ values in any T. s. monachus feathers and the earlier grown T. s. savana feathers. To the best of our knowledge, this is the first research into trophic niche patterns of long-distance Neotropical austral migrant birds.

\section{Methods}

\section{Field Methods}

T. s. savana breed during the austral summer (mid-October to January) from central Brazil to central Argentina (Tuero, Jahn, \& MacPherson, 2019; Marini, Barbet-Massin, Lopes, \& Jiguet, 2009; Mobley, 2004) and overwinter in northern South America (primarily in the Orinoco and northern Amazon River basins; Chesser, 1994; Tuero, Jahn, \& MacPherson, 2019) with the earliest arriving on the wintering area mid-April and beginning spring migration in mid-July (Jahn et al., 2019; Figs. 1 and 2). T. s. savana molt from mid-March to mid-August (Jahn et al., 2016a; Pyle, 1997, the present study; Fig. 1). T. s. monachus is a sedentary sister subspecies that breeds from January through April in northern South America (Gómez-Bahamón et al., 2020; Mobley, 2004), although nests have been found in Venezuela as late as October (Mobley, 2004). T. s. monachus molt from July to September (Pyle, 1997), and individuals were in molt during the sampling for this study (Fig. 1). Descriptions of molt characteristics of all individuals can be found in Appendix 1 (Table A1.1). 

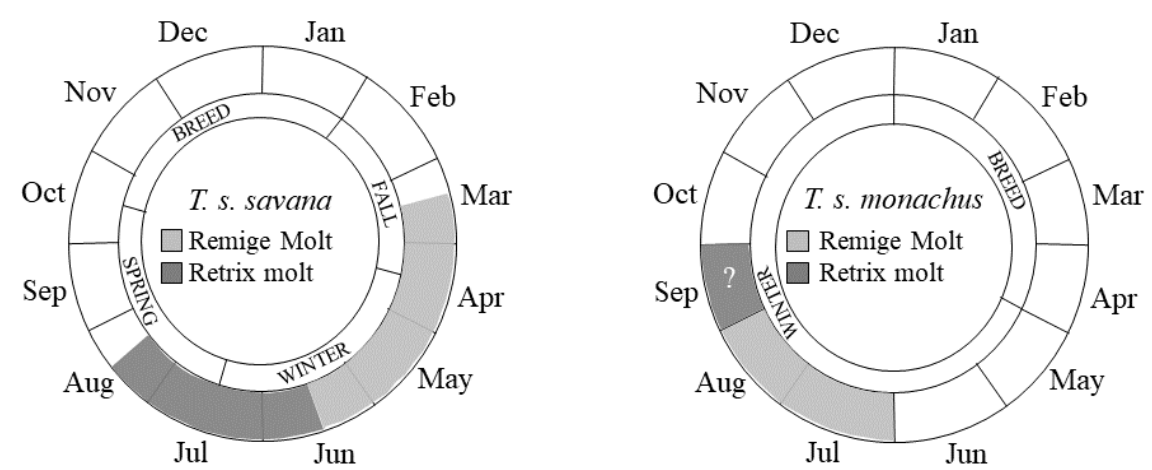

Figure 1. Annual life cycles of Neotropical austral migrant T. s. savana (left), and tropical sedentary T. s. monachus (right). The migratory $T$. s. savana migrates in the time-period marked FALL to overwinter in northern South America, beginning its annual molt by molting wing feathers (remiges), and completing its molt by molting tail feathers (retrices) prior to departing on spring migration (SPRING in the figure) to the breeding grounds. T. savana have very long tail feathers which may play an additional role in seasonal energetic requirements.

T. savana sally and glean for arthropods and are known to eat berries and palm fruit outside of the breeding season (Mobley, 2004). In northern Venezuela, migratory T. s. savana had been observed consuming seasonally abundant cactus fruits (Maggie MacPherson, pers. observation). In central Venezuela, both subspecies had been observed foraging nocturnally on aerial insects surrounding streetlamps (Maggie MacPherson, pers. observation). In Guyana, both subspecies were observed consuming fruits from the locally known 'beshawud tree' (Trema micrantha) as well as from mistletoe (Loranthaceae; whose seeds were often regurgitated onto fences, vegetation, and inside of bird holding bags) at field sites during the study (Maggie MacPherson \& Alex Jahn, pers. observation). In an effort to match stable nitrogen isotope values with field observations of foraging behavior, we walked twenty $5 \mathrm{~km}$ transects separated by $1 \mathrm{~km}$ beginning at 6 a.m. from 19 July - 6 August 2014. This effort rarely yielded foraging 
observations (a single foraging event was observed on 19 July when a $T$. s. monachus flew from the ground to catch what appeared to be a moth), and did not generally yield many observations of the study species. Although the standardized approach may be appropriate in habitats where individuals would be concentrated or abundant, we recommend that for wide ranging species a more haphazard or motorized effort to observe diurnal foraging behavior would be more appropriate.

We caught and sampled individuals of these two subspecies of $T$. savana using mist-nets surrounding nocturnal roosts at Dadanawa Ranch $\left(2^{\circ} 49.469^{\prime} \mathrm{N}, 59^{\circ} 30.560^{\prime} \mathrm{W}\right)$ in Guyana in July 2014 (Fig. 2). We used standard protocols to band and release all birds (Ralph, Geupel, Pyle, Martin, \& DeSante, 1993). We distinguished T. s. savana from T. s. monachus following Pyle (1997), first in the hand during field work, and then later by reviewing photographs taken of the birds while in the hand. We primarily used the presence of a notch on primary feather 8 (P8) exclusive to T. s. savana, in addition to the darker grey back color and less extensive white collar of $T$. s. savana compared to that of T. s. monachus (Pyle, 1997). Our open data is available in Appendix 1 (Table A1.1). 


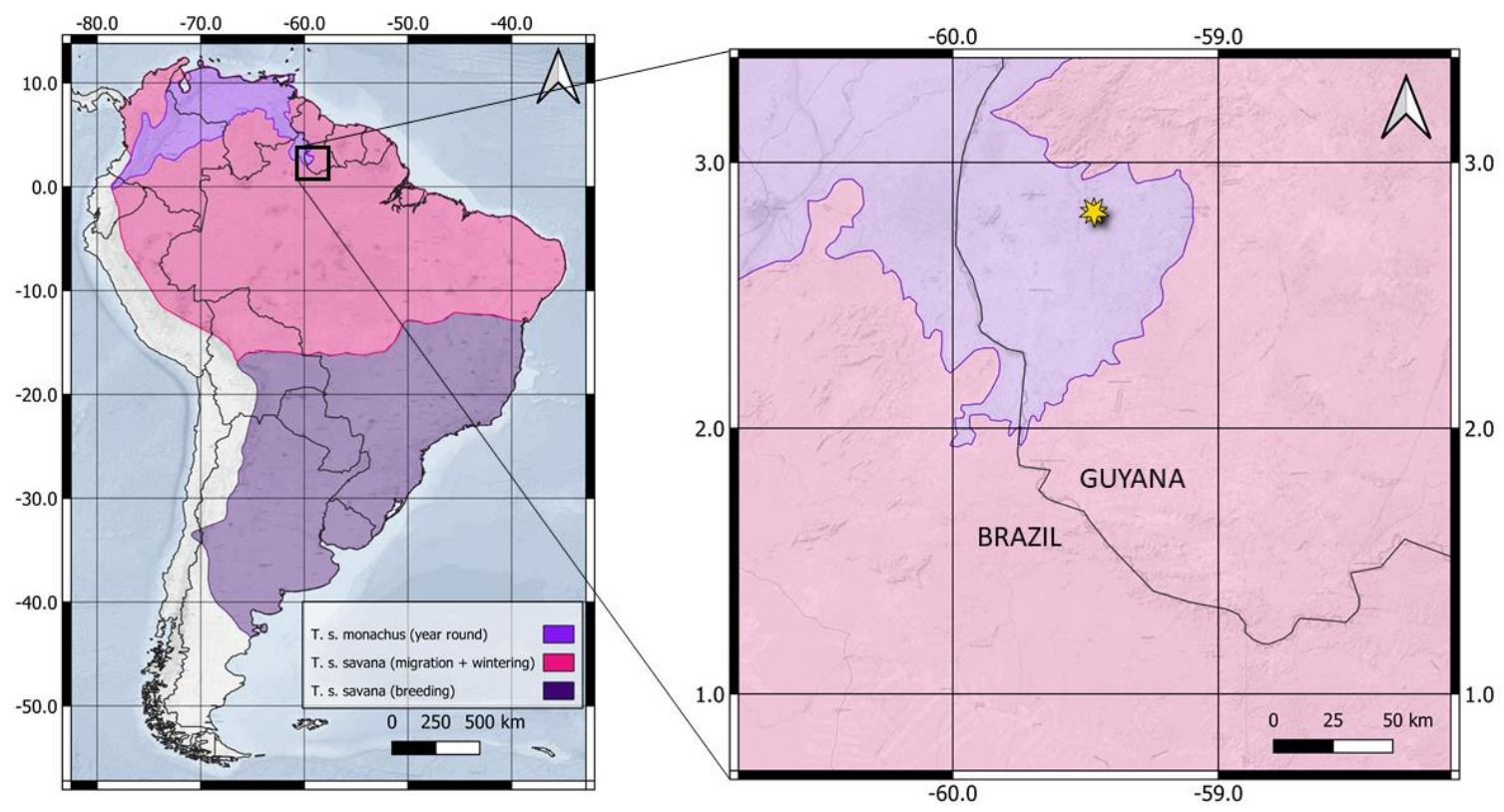

Figure 2. Map of the distribution of T. savana subspecies in South America constructed from BirdLife International species distribution data. The field site location is identified by a star in the box on the right.

For stable nitrogen isotope analysis, we clipped the first primary feather (P1) and the sixth secondary feather (S6) and pulled the third tail feather (R3) from 21 T. s. savana and 6 T. s. monachus individuals in 2014. These were usually from the right wing (P1, S6) and right side of the tail (R3). The sampling design followed selecting feathers grown at the beginning (P1), middle (S6) and end (R3) of molt (Jahn et al., 2016a; Pyle, 1997). Feather samples were stored individually in manila coin envelopes and kept in darkness inside a sealed carton at room temperature while in the field. Prior to export from Guyana, samples were heat-treated at $100{ }^{\circ} \mathrm{C}$ for 20 minutes in compliance with USDA regulations.

Stable nitrogen isotope analysis of wild $T$. savana feather samples 
Once at Tulane University in New Orleans, feathers were removed from envelopes, washed in Alconox and then rinsed in deionized water prior to being dried (Paritte \& Kelly, 2009). A subsample (1 mg +/- $0.2 \mathrm{mg}$ ) was clipped from the distal end of each feather and sealed in a tin capsule. The University of California, Davis Stable Isotope Facility performed all isotope analyses. Stable nitrogen isotope ratios were determined on nitrogen gas produced by combustion of samples in an elemental analyzer interfaced to a continuous flow isotope ratio mass spectrometer (PDZ Europa ANCA-GSL; PDZ Europa 20 - 20 isotope ratio mass spectrometer; Sercon Ltd., Cheshire, UK). The ratio of stable isotopes $\left({ }^{15} \mathrm{~N} /{ }^{14} \mathrm{~N}\right)$ was expressed in delta $(\delta)$ notation in per-thousand units $(\%)$ : $\left[\left(\mathrm{R}_{\text {sample }} / \mathrm{R}_{\text {standard }}\right)-1\right] \times 1000$, where $\delta$ is the relative isotope ratio of the sample to the standard. $\mathbf{R}_{\text {sample }}$ and $\mathbf{R}_{\text {standard }}$ are the fractions of heavy to light isotopes in the sample and standard, respectively. The standard for nitrogen was atmospheric nitrogen.

\section{Data Analyses}

To test whether the ratio of heavy to light nitrogen isotopes in tissues (hereafter, $\delta^{15} \mathrm{~N}$ values) became depleted over time in $T$. s. savana compared to T. s. monachus, we performed an ANOVA to compare the $\delta^{15} \mathrm{~N}$ values of feathers grown along the molting schedule with feather and subspecies as fixed effects and individual as a random effect. We then performed a Tukey's post hoc test on the mixed model to assess differences between feather $\delta^{15} \mathrm{~N}$ values across both subspecies. Note: Prior to conducting the ANOVA, we used AIC to validate that including neither sex nor age improved linear model comparisons of $\delta^{15} \mathrm{~N}$ values of each feather $(\mathrm{P} 1, \mathrm{~S} 6$, R3) between each subspecies. All statistical analyses were performed in program R v3.5.3 (R Development Core Team, 2020). Code is available in Appendix 2. 
The values of $\delta^{15} \mathrm{~N}$ values are expected to be indicative of the trophic position of an organism when the tissues was being built and in the given environment (Post, 2002).

Comparisons of the $\delta^{15} \mathrm{~N}$ values in bird blood have been linked to source fruit and arthropod foods with tropical forest fruits having low $\delta^{15} \mathrm{~N}$ values and arthropods and spiders having higher $\delta^{15} \mathrm{~N}$ values (in a tropical forest; McKinnon et al., 2017). Differences between $\delta^{15} \mathrm{~N}$ values from feathers in other comparative research of sympatric migratory and sedentary congeners has supported the notion that trophic niche changes reflect seasonal or physiological changes rather than interspecific interactions such as competitive exclusion (cerrado Elaenia flycatcher species; Guaraldo et al., 2018). Thus, we expect a comparison of $\delta^{15} \mathrm{~N}$ values from feathers grown at the same site and time of year in our tropical savanna ecosystem to accurately reflect the trophic niche of T. savana individuals.

\section{Results}

We found that there were significant differences in $\delta^{15} \mathrm{~N}$ values between $T$. s. savana and $T$. $s$. monachus feathers $\left(\mathrm{F}_{1,2}=5.712, P=0.00609\right)$. In Tukey's post hoc tests we found that $\delta^{15} \mathrm{~N}$ value of T. s. savana P1 differed from both S6 (P=0.0006) and R3 (0.0.0120) feathers. None of the $\delta^{15} \mathrm{~N}$ values of T. s. monachus differed from one another, but P1 feathers differed significantly between subspecies $(\mathrm{P}=0.0037)$. There were no other significant differences between $\delta^{15} \mathrm{~N}$ values of feathers. Mean $\delta^{15} \mathrm{~N}$ values $+/$ - standard deviation and sample sizes can be found for each subspecies and feather type in Table 1, and the values with respect to when feathers are estimated to have been grown across the annual cycle for each subspecies in Fig. 3. Our open data are available in Appendix 1 (Table A1.2). 


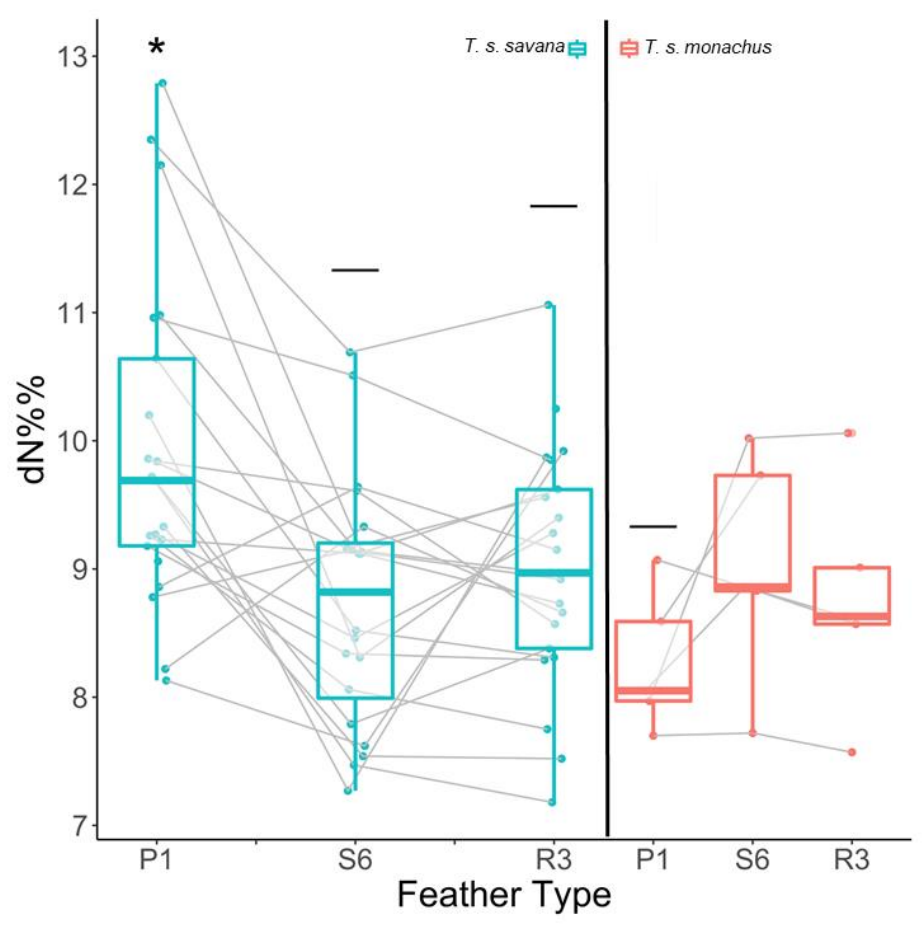

Figure 3. Stable nitrogen isotope signatures (y-axis) of feathers grown across the year in migratory T. s. savana (blue) sedentary T. s. monachus (pink) individuals. Feathers collected from the same individual are connected via grey lines. An asterisk denotes a significant difference between mean $T$. s. savana $\mathrm{P} 1$ feather isotope signature and $T$. s. savana S6, R3 and $T$. s. monachus P1 (denoted by dashes). Note: The x-axis scale reflects the longer molt duration expected for T. s. savana compared to T. s. monachus. The boxes reflected the median, and first and third quartiles, and the whiskers extend from the hinge to the largest (or smallest for the whisker going out from the first quartile) point no further than $1.5 \mathrm{x}$ the inter-quartile range (the distance between the first and third quartiles).

Table 1. Mean stable nitrogen isotope ratio values across flight feathers in a migratory (T. $s$. savana) and sedentary (T. s. monachus) subspecies. Sample sizes vary with a subspecies because 
all feathers could not be sampled when they were missing as birds were in active molt during the study.

\begin{tabular}{|c|c|c|c|}
\hline Subspecies & Feather & Sample Size & Mean (sd) \\
\hline \multirow[t]{3}{*}{ T. s. savana } & P1 & 21 & $9.928(1.1294)$ \\
\hline & S6 & 20 & $8.742(0.9717)$ \\
\hline & R3 & 21 & $9.011(0.9460)$ \\
\hline \multirow[t]{3}{*}{ T. s. monachus } & $\mathrm{P} 1$ & 5 & $8.276(0.5490)$ \\
\hline & S6 & 5 & $9.032(0.9021)$ \\
\hline & R3 & 5 & $8.692(0.8086)$ \\
\hline
\end{tabular}

\section{Discussion}

We did not find evidence that a South American austral migratory bird changes its trophic niche in preparation for spring migration, because the trophic niche shift we observed occurs during the middle of the molting period (when S6 is molted) which is months ahead of spring migration. In contrast with our prediction, we found evidence that the migratory $T$. $s$. savana shifts from a higher trophic niche at the beginning of the molt period to a lower trophic niche during the middle of the molt cycle. Additionally, we did not detect a change in $\delta^{15} \mathrm{~N}$ values of feathers grown across the molt schedule of the sedentary subspecies; however, these values were not higher than that of the migratory subspecies, which only partially supports our second prediction.

There are several alternative hypotheses that we think could explain the higher trophic niche reflected in $\delta^{15} \mathrm{~N}$ values of $\mathrm{P} 1$ feathers of $T$. s. savana. One is that it is a statistical artifact of high variability and sparse sampling, i.e., $\delta^{15} \mathrm{~N}$ values were highly variable among feather types (which seems likely given the high variability among individuals) and we only selected 
three feathers from the molt sequence. Another hypothesis is that the higher $\delta^{15} \mathrm{~N}$ values of P1 reflect selection of prey resources based on nutritional deficits accumulated during fall migration. This explanation does not seem highly likely because fall migration is generally slower than spring migration in passerines (Nilsson, Klaassen, \& Alerstam, 2013), with shorter flights and longer stopovers providing ample refueling opportunities. A tracking study of $T$. $s$. savana shows that they are no exception because $T$. s. savana spends more days on fall migration and travels at a lower rate (km/day) than during spring migration (Jahn et al., 2016b). However, additional data on body molt for this species may signal an unappreciated cost for fall migration in these long-distance migrants (Jahn et al., 2017). The explanation that we think most likely is that a trophic niche shift could be caused by differences in food availability. Locations of the migratory $T$. s. savana have been shown to correlate with high precipitation across their nonbreeding grounds when invertebrate abundance increases during the wet season in northern South America (MacPherson et al., 2018). We cannot reject an evolutionary explanation that marries these latter two ideas, such that foraging at a higher trophic niche is important for refueling after fall migration and that timing of the beginning of molt to coincide with the beginning of the wet season is advantageous. However, because our dataset does not include feathers molted by the sedentary T. s. monachus during the time that the migratory $T$. s. savana began molting (because of differences in the timing of flight feather molt between these taxa) our results primarily support the idea that both subspecies are simply consuming what is available to them.

The overall lack of a diet switch signal prior to migration by the migratory subspecies suggests that Neotropical austral migrants do not prepare for spring migration in the same way as do their Northern Hemisphere counterparts. Several lines of evidence suggest that this is the 
case. First, seasonality in the Southern Hemisphere is more buffered than in most of the Northern Hemisphere, potentially translating to greater flexibility in the length of the breeding period (Rowley \& Russel, 1991). Second, primary productivity at tropical and south-temperate latitudes is highly variable between years (e.g., Nobre et al., 2006). Thus, the combination of more seasonally buffered seasons and highly unpredictable annual productivity could translate to a lower selective pressure to arrive as early as possible to South American breeding grounds, as compared to those breeding in the Northern Hemisphere (Jahn et al., 2020). If so, Neotropical austral migrants may employ a relatively conservative spring migration strategy, resulting in a lower need to fatten prior to spring migration. Thus, Neotropical austral migrants may exhibit little or no diet shift prior to spring migration as compared to migratory birds that breed in the Northern Hemisphere, which represents an interesting line of future research across these two migratory systems.

The evidence we present signals a potential trophic niche shift between the beginning and middle of flight feather molt in the migratory $T$. s. savana, and is similar to those seen in other studies, but may not reflect a diet shift from invertebrates to fruit. Fractionation of $\delta^{15} \mathrm{~N}$ values in feathers are enriched compared to dietary intake by about 1.1 to 3.0 depending upon species and $\operatorname{diet}$ (K. A. Hobson \& Clark, 1992). Even if the higher end of enrichment is assumed for the samples in our study, we would not reach the $\delta^{15} \mathrm{~N}$ values from fruits found in McKinnon et al. (2017), although that study found no significant difference between $\delta^{15} \mathrm{~N}$ values in fruit and Orthopterans. Likewise, Guaraldo et al. (2018) found that $\delta^{15} \mathrm{~N}$ values in feathers grown when individuals were estimated to be eating mostly spiders and beetles had lower values than those we found. A more robust claim for evidence of a trophic niche shift using $\delta^{15} \mathrm{~N}$ values would be to link $\delta^{15} \mathrm{~N}$ values in animal tissues with specific food items available in their habitat, to draw 
any specific conclusions on probable diet using a Bayesian mixing model (Guaraldo et al., 2018; McKinnon et al., 2017).

We suggest that for omnivorous species with large daily ranges during the non-breeding season like T. savana, there is a likelihood of overestimating the use of static food resources such as fruit compared to small (hard to see), mobile and sometimes volant prey items such as invertebrates. More creative, invasive or collection-based approaches could yield better information on diet including using metabarcoding or visually inspecting stomach contents after forcing regurgitation using emetics or after removing the stomachs from collected specimens for natural history collections. However, this approach would only reflect the diet at the time of capture. An alternative approach to testing taxon- and habitat-specific fractionation values would be to conduct aviary experiments on captive individuals to measure $\delta^{15} \mathrm{~N}$ values in tissues grown with diets of specific trophic compositions. All of these suggestions are highly field intensive and would benefit from being paired with research already in motion such as collecting expeditions at active research collections or working with species where successful captive studies have already taken place.

Connecting the diet of birds with their life history strategies is important for understanding how nutrient availability is accessed in seasonal environments to meet annual life history needs. Many migratory bird species have been shown to 'niche switch' between breeding and non-breeding ranges (Martínez-Meyer, Peterson, \& Navarro-Sigüenza, 2004; Nakazawa, Peterson, Martinez-Meyer, \& Navarro-Sigüenza, 2004), which has spurred the development of novel, temporally explicit distribution models for migratory taxa (MacPherson et al., 2018; Williams, Willemoes, \& Thorup, 2017). Previous studies have found that migratory birds typically niche switch during the breeding season and that niche conservatism is an ancestral trait 
(Dingle, 2016; Gomez, Tenorio, Montoya, \& Cadena, 2016). Although inferring the ecological niche of species is important for designating appropriate habitat for conservation purposes, identifying predictive species distribution models for migratory species using proxies for species-habitat relationships (such as the widely used BIOCLIM variables) would be complicated in the case of niche-switchers if the value of the habitat variable is not a proxy for year-round food requirements.

The present study supported a comparative test for a trophic niche shift relevant to life history strategies in the relatively poorly studied Neotropical austral bird migration system, in which birds migrate wholly within South America (Chesser, 1994). Our results were unique compared to previous research on migratory birds in the Northern Hemisphere, many of which demonstrate a switch in foraging at higher to lower trophic levels prior to spring migration, because the potential shift in trophic niche occurred much earlier than expected. Thus, a higher foraging trophic niche early in the molt of the migratory $T$. s. savana is likely related to seasonal changes in food availability as the wet season concludes (Alan, McWilliams, \& McGraw, 2013; Baird, 1980; McCabe \& Olsen, 2015; Pérez-Tris \& Tellería, 2002). Our comparative approach provides directions for future research into the trade-offs between differing life history strategies. Future research linking patterns in $\delta^{15} \mathrm{~N}$ values in feathers to diets with known compositions across various habitat types would be helpful to improve the utility of this approach for inferring more specific metabolic processes across avian taxa.

\section{Acknowledgements}

We thank B. O'Shea, S. Hearn, D. Cormier, S. Ameerally and W. Jones for critical assistance in the field. This research was undertaken in compliance with an IACUC from Tulane University (\# 0424R), and research permissions from the EPA in Guyana (\# 071414 BR 028). This work was 
supported by a research grant from Fundação de Amparo à Pequisa do Estado de São Paulo [\#2012/17225-2; AEJ], a research grant from the Ecology and Evolutionary Biology Department at Tulane University [MPM].

\section{Literature Cited}

Alan, R. R., McWilliams, S. R., \& McGraw, K. J. (2013). The importance of antioxidants for avian fruit selection during autumn migration. The Wilson Journal of Ornithology, 125(3), 513-525. doi:10.1676/13-014.1

Baird, J. W. (1980). The selection and use of fruit by birds in an eastern forest. The Wilson Bulletin, 92(1), 63-73.

Battley, P. F., Dietz, M. W., Piersma, T., Dekinga, A., Tang, S., \& Hulsman, K. (2001). Is longdistance bird flight equivalent to a high-energy fast? Body composition changes in freely migrating and captive fasting great knots. Physiological and Biochemical Zoology: PBZ, 74(3), 435-449. doi:10.1086/320432

Buchan, C., Gilroy, J. J., Catry, I., \& Franco, A. M. A. (2020). Fitness consequences of different migratory strategies in partially migratory populations: A multi-taxa meta-analysis. Journal of Animal Ecology, 89(3), 678-690. doi:10.1111/1365-2656.13155

Chesser, R. T. (1994). Migration in South America: an overview of the austral system. Bird Conservation International (Vol. 4). Retrieved from https://www.cambridge.org/core/services/aop-cambridgecore/content/view/EA35BDAF242019BB98586713236ACCBC/S0959270900002690a.pdf/ migration_in_south_america_an_overview_of_the_austral_system.pdf 
Dingle, H. (2016). Austral Ornithology Bird migration in the southern hemisphere: a review comparing continents. Emu. doi:10.1071/MU08010

Fitzpatrick, J., Bates, J., Bostwick, K., Caballero, I., Clock, B., Farnsworth, A., ... Zimmer, K. (2004). Family Tyrannidae (Tyrant-flycatchers). In J. del Hoyo, A. Elliott, \& D. A. Christie (Eds.), Handbook of the Birds of the World - Volume 9 Contingas to Pipits and Wagtails (pp. 419-425). Lynx Edicions.

Gómez-Bahamón, V., Márquez, R., Jahn, A. E., Miyaki, C. Y., Tuero, D. T., Laverde-R, O., ... Cadena, C. D. (2020). Speciation Associated with Shifts in Migratory Behavior in an Avian Radiation. Current Biology, 30(7), 1312-1321.e6. doi:10.1016/j.cub.2020.01.064

Gomez, C., Tenorio, E. A., Montoya, P., \& Cadena, C. D. (2016). Niche-tracking migrants and niche- switching residents : evolution of climatic niches in New World warblers (Parulidae). Proceedings of the Royal Society B: Biological Sciences, 283, 20152458. doi:rspb.2015.2458

Guaraldo, A. C., Kelly, J. F., \& Marini, M. Â. (2018). Independent trophic behavior and breeding success of a resident flycatcher and a coexisting migratory congener. Austral Ecology, 1-12. doi:10.1111/aec.12660

Hobson, K. A., \& Clark, R. G. (1992). Assessing Avian Diets Using Stable Isotopes II: Factors Influencing Diet-Tissue Fractionation. The Condor, 94(1), 189-197. doi:10.2307/1368808

Hobson, K. A., \& Bairlein, F. (2003). Isotopic fractionatin and turnover in captive garden warblers (Sylvia borin): implications for delineating dietary and migratory associations in wild passerines. Canadian Journal of Zoology, 81(9), 1630-1635. doi:10.1139/z03-140 
Jahn, A. E., Giraldo, J. I., MacPherson, M., Tuero, D. T., Sarasola, J. H., Cereghetti, J., ... Morales, M. V. (2016a). Demographic variation in timing and intensity of feather molt in migratory Fork-tailed Flycatchers (Tyrannus s. savana). Journal of Field Ornithology, 87(2). doi:10.1111/jofo.12147

Jahn, A. E., Bejarano, V., Guzmán, M. B., Brown, L. M., Carvalho Provinciato, I. C., Cereghetti, J., ... Tuero, D. T. (2017). Molting while breeding? Lessons from New World Tyrannus Flycatchers. Journal of Ornithology, 158(4), 1061-1072. doi:10.1007/s10336-017-1464-5

Jahn, A. E., Cereghetti, J., Cueto, V. R., Hallworth, M. T., Levey, D. J., Marini, M., ... Tuero, D. T. (2019). Breeding latitude predicts timing but not rate of spring migration in a widespread migratory bird in South America. Ecology and Evolution, 9(10), 5752-5765. doi:10.1002/ece3.5159

Jahn, A. E., Cueto, V. R., Fontana, C. S., Guaraldo, A. C., Levey, D. J., Marra, P. P., \& Ryder, T. B. (2020). Bird migration within the Neotropics, 137(2), 1-23. doi:10.1093/auk/ukaa033

Jahn, A. E., \& Tuero, D. T. (2013). Overview - Fork-tailed Flycatcher (Tyrannus savana) Neotropical Birds. Retrieved March 2, 2017, from http://neotropical.birds.cornell.edu/portal/species/overview?p_p_spp=482636

Kimmitt, A. A., Sinkiewicz, D. M., \& Ketterson, E. D. (2020). Seasonally sympatric songbirds that differ in migratory strategy also differ in neuroendocrine measures. General and Comparative Endocrinology, 285, 113250. doi:https://doi.org/10.1016/j.ygcen.2019.113250

Klaassen, M., \& Biebach, H. (1994). Energetics of fattening and starvation in the long-distance migratory garden warbler Sylvian borin during the migratory phase. Journal of Comparative 
Physiology - B, 164, 362-371.

Klaassen, M., Lindström, Å., \& Ziljstra, R. (1997). Composition of Fuel Stores and Digestive Limitations to Fuel Deposition Rate in the Long- Distance Migratory Thrush Nightingale, Luscinia luscinia. Physiological Zoology, 70(1), 125-133.

Lindström, A., \& Piersma, T. (1993). Mass changes in migrating birds : the evidence for fat and protein storage re-examined. Ibis, 135, 70-78. doi:10.1111/j.1474-919X.1993.tb02811.x

Tellería, J. L., Blázquez, M., De La Hera, I., \& Pérez-Tris, J. (2013). Migratory and resident Blackcaps Sylvia atricapilla wintering in southern Spain show no resource partitioning. Ibis, 155(4), 750-761. doi:10.1111/ibi.12078

MacPherson, M. P., Jahn, A. E., Murphy, M. T., Kim, D. H., Cueto, V. R., Tuero, D. T., \& Hill, E. D. (2018). Follow the rain? Environmental drivers of Tyrannus migration across the New World. The Auk, 135, 881-894. doi:10.1642/AUK-17-209.1

Marini, M. Â., Barbet-Massin, M., Lopes, L. E., \& Jiguet, F. (2009). Predicted climate-driven bird distribution changes and forecasted conservation conflicts in a neotropical savanna. Conservation Biology, 23(6), 1558-1567. doi:10.1111/j.1523-1739.2009.01258.x

Martínez-Meyer, E., Peterson, A. T., \& Navarro-Sigüenza, A. G. (2004). Evolution of seasonal ecological niches in the Passerina buntings (Aves: Cardinalidae). Proceedings of the Royal Society B: Biological Sciences, 271(1544), 1151-1157. doi:10.1098/rspb.2003.2564

McCabe, J. D., \& Olsen, B. J. (2015). Tradeoffs between predation risk and fruit resources shape habitat use of landbirds during autumn migration. The Auk, 132(4), 903-913. 
doi:10.1642/AUK-14-213.1

McKinnon, E. A., Kyser, K. T., \& Stutchbury, B. J. M. (2017). Does the proportion of arthropods versus fruit in the diet influence overwintering condition of an omnivorous songbird? Journal of Field Ornithology, 0(0), 1-15. doi:10.1111/jofo.12187

Mobley, J. M. (2004). Fork-tailed Flycatcher Tyrannus savana. In J. del Hoyo, A. Elliot, \& D. Christie (Eds.), Handbook of the birds of the world. Volume 9. Contingas to pipits and wagtails (p. 425). Barcelona: Lynx Edicions.

Najar, N., \& Benedict, L. (2019). The relationship between latitude, migration and the evolution of bird song complexity. Ibis, 161(1), 1-12. doi:10.1111/ibi.12648

Nakazawa, Y., Peterson, A., Martinez-Meyer, E., \& Navarro-Sigüenza, A. G. (2004). Seasonal niches of Nearctic-Neotropical migratory birds: implications for the evolution of migration. The Auk, 121(2), 610-618. doi:10.1642/0004-8038(2004)121

Nelson, D. A., Marler, P., \& Morton, M. L. (1996). Overproduction in song development: An evolutionary correlate with migration. Animal Behaviour, 51(5), 1127-1140. doi:10.1006/anbe.1996.0114

Neto, J. M., Gordinho, L., Belda, E. J., Marín, M., Monrós, J. S., Fearon, P., \& Crates, R. (2013). Phenotypic Divergence among West European Populations of Reed Bunting Emberiza schoeniclus: The Effects of Migratory and Foraging Behaviours. PLoS ONE, 8(5). doi:10.1371/journal.pone.0063248

Newsholme, E. A., \& Leech, A. R. (1985). Biochemistry for the Medical Sciences. New York: 
John Wiley and Sons Inc.

Nilsson, C., Klaassen, R. H. G., \& Alerstam, T. (2013). Differences in Speed and Duration of Bird Migration between Spring and Autumn, 181(6). doi:10.1086/670335

Nobre, P., Marengo, J. A., Cavalcanti, I. F. A., Obregon, G., Barros, V., Camilloni, I., ... Ferreira, A. G. (2006). Seasonal-to-decadal predictability and prediction of South American climate. Journal of Climate, 19(23), 5988-6004. doi:10.1175/JCLI3946.1

Paritte, J. M., \& Kelly, J. F. (2009). Effect of cleaning regime on stable-isotope ratios of feathers in Japanese Quail (Coturnix japonica). Auk2, 126, 165-174.

Pérez-Tris, J., \& Tellería, J. L. (2002). Migratory and sedentary blackcaps in sympatric nonbreeding grounds: Implications for the evolution of avian migration. Journal of Animal Ecology, 71(2), 211-224. doi:10.1046/j.1365-2656.2002.00590.x

Pond, C. M. (1981). Storage. In C. R. Townsend \& P. Calow (Eds.), Physiological ecology: an evolutionary approach to resrouce use. (pp. 190-219). Oxford: Blackwell.

Post, D. M. (2002). Using stable isotopes to estimate trophic position: Models, methods, and assumptions. Ecology, 83(3), 703-718. doi:10.1890/00129658(2002)083[0703:USITET]2.0.CO;2

Pyle, P. (1997). Identification Guide to North American Birds, Part 1: Columbidae to Ploceidae. Bolinas, California: Slate Creek Press.

Ralph, C. J., Geupel, G. R., Pyle, P., Martin, T. E., \& DeSante, D. F. (1993). Handbook of Field Methods for Monitoring Landbirds. Director, 144(1), 1-41. Retrieved from 
http://digitalcommons.unl.edu/cgi/viewcontent.cgi?article=1104\&amp; context=usdafsfacpu b

Rowley, I., \& Russel, E. (1991). Demography of passerines in the temperate southern hemisphere. In C. M. Perrins, J.-D. Lebreton, \& J. G. M. Hirans (Eds.), Bird population studies: Relevance to conservation and management (pp. 22-44). Oxford: Oxford University Press.

Smith, R. J., \& Moore, F. R. (2005). Arrival timing and seasonal reproductive performance in a long-distance migratory landbird. Behavioral Ecology and Sociobiology, 57(3), 231-239. doi:10.1007/s00265-004-0855-9

Tomotani, B. M., Caglar, E., de la Hera, I., Mateman, A. C., \& Visser, M. E. (2017). Early arrival is not associated with more extra-pair fertilizations in a long-distance migratory bird. Journal of Avian Biology, 48(6), 854-861. doi:10.1111/jav.01317

Tuero, D. T., Jahn, A. E., \& MacPherson, M. P. (2019). Bird Migration in South America: The Fork-tailed Flycatcher (Tyrannus savana) as a Case Study. In J. C. Reboreda, V. D. Fiorini, \& Tuero (Eds.), Behavioral Ecology of Neotropical Birds (pp. 133-154). Gewerbestrasse, Switzerland: Springer. doi:10.1007/978-3-030-14280-3

Visser, M. E., Holleman, L. J. M., \& Gienapp, P. (2006). Shifts in caterpillar biomass phenology due to climate change and its impact on the breeding biology of an insectivorous bird. Oecologia, 147(1), 164-172. doi:10.1007/s00442-005-0299-6

Williams, H. M., Willemoes, M., \& Thorup, K. (2017). A temporally explicit species distribution model for a long distance avian migrant, the common cuckoo. Journal of Avian Biology, 
48(12), 1624-1636. doi:10.1111/jav.01476 


\section{Appendix 1}

Table A1.1. Banding data for T. savana individuals. All individuals were captured in July 2014. Juvenile birds without distinguishing characters were not sexed (i.e., molting wing feathers prohibiting accurate wing measurements and presence of juvenile primary feathers that lack notches, which are necessary for sexing). See Ralph, Geupel, Pyle, Martin \& DeSante (1993) for explanation of methods.

\begin{tabular}{|c|c|c|c|c|c|c|c|c|c|c|c|c|c|c|c|}
\hline $\begin{array}{c}\text { Individual } \\
\text { ID }\end{array}$ & Date & $\begin{array}{c}\text { Fat } \\
\text { Score }\end{array}$ & $\begin{array}{l}\text { Muscle } \\
\text { Score }\end{array}$ & Age & How Aged & Sex & How Sexed & Body Molt & $\begin{array}{c}\text { Feather } \\
\text { Wear }\end{array}$ & $\begin{array}{l}\text { Wing } \\
\text { Molt } \\
(\mathrm{Y} / \mathrm{N}) \\
\end{array}$ & Wing Feathers in Molt & $\begin{array}{l}\text { Tail } \\
\text { Molt } \\
(\mathrm{Y} / \mathrm{N}) \\
\end{array}$ & $\begin{array}{l}\text { Tail Feathers } \\
\text { in Molt }\end{array}$ & Subspecies & $\begin{array}{l}\text { How subspecies } \\
\text { IDd }\end{array}$ \\
\hline $2661-39624$ & $7 / 21$ & 0 & 2 & Adult & Plumage & Male & Primary notch & Heavy & Medium & $\mathrm{Y}$ & $\begin{array}{l}\text { Right: P7, S2, T3; } \\
\text { Left: P7, S2, T1 }\end{array}$ & $\mathrm{Y}$ & $\begin{array}{l}\text { R6, R2, R1 } \\
\text { (symmetrical) }\end{array}$ & monachus & $\begin{array}{l}\text { Primary notch } \\
\text { lacking on P8 }\end{array}$ \\
\hline $2661-39627$ & $7 / 21$ & 2 & 3 & Adult & Plumage & Female & No primary notch & None & None & $\mathrm{N}$ & & $\mathrm{N}$ & & savana & Back coloration \\
\hline $2661-39628$ & $7 / 21$ & 1 & 1 & Adult & Plumage & Female & No primary notch & Heavy & None & $\mathrm{N}$ & & $\mathrm{Y}$ & $\begin{array}{l}\text { R6 } \\
\text { (symmetrical) }\end{array}$ & savana & Back coloration \\
\hline $2661-39629$ & $7 / 21$ & 3 & 2 & Adult & Plumage & Male & Primary notch & None & None & $\mathrm{N}$ & & $\mathrm{N}$ & & savana & $\begin{array}{l}\text { Primary notch on } \\
\text { P8 }\end{array}$ \\
\hline $2661-39630$ & $7 / 21$ & 2 & 2 & Adult & Plumage & Male & Primary notch & Indication & None & $\mathrm{N}$ & & $\mathrm{Y}$ & $\begin{array}{l}\text { R6 } \\
\text { (symmetrical) }\end{array}$ & savana & $\begin{array}{l}\text { Primary notch on } \\
\text { P8 }\end{array}$ \\
\hline $2661-39635$ & $7 / 21$ & 1 & 1 & Adult & Plumage & Male & Primary notch & $\begin{array}{c}\text { Light } \\
\end{array}$ & None & $\mathrm{Y}$ & $\begin{array}{l}\text { Right: P10; } \\
\text { Left: P10, S5 }\end{array}$ & $\mathrm{Y}$ & $\begin{array}{l}\text { R6 } \\
\text { (symmetrical) }\end{array}$ & savana & $\begin{array}{l}\text { Primary notch on } \\
\text { P8 }\end{array}$ \\
\hline $2661-39639$ & $7 / 21$ & 1 & 1 & Adult & Plumage & Male & Primary notch & None & Light & $\mathrm{Y}$ & $\begin{array}{l}\text { Right: P10, S5; } \\
\text { Left: P10, S4, S5 }\end{array}$ & $\mathrm{Y}$ & $\begin{array}{l}\text { R6, R5 } \\
\text { (symmetrical) }\end{array}$ & savana & $\begin{array}{l}\text { Primary notch on } \\
\text { P8 }\end{array}$ \\
\hline $2661-39645$ & $7 / 22$ & 3 & 2 & $\begin{array}{l}\text { Adult } \\
\end{array}$ & Plumage & Male & Primary notch & Medium & Indication & $\mathrm{N}$ & & $\mathrm{Y}$ & $\begin{array}{l}\text { R6 } \\
\text { (symmetrical) }\end{array}$ & savana & $\begin{array}{l}\text { Primary notch on } \\
\text { P8 }\end{array}$ \\
\hline $2661-39646$ & $7 / 22$ & 1 & 2 & Adult & Plumage & Male & Primary notch & None & None & $\mathrm{Y}$ & $\begin{array}{l}\text { P9, P8, P7, P6, P5, P4, P3 } \\
\text { (symmetrical) }\end{array}$ & $\mathrm{N}$ & & savana & $\begin{array}{l}\text { Primary notch on } \\
\text { P8 }\end{array}$ \\
\hline $2661-39648$ & $7 / 22$ & 1 & 2 & Adult & Plumage & Female & No primary notch & Indication & Light & $\mathrm{Y}$ & Left: P10 & $\mathrm{Y}$ & Left: R6 & savana & Back coloration \\
\hline $2661-39653$ & $7 / 22$ & 1 & 3 & Adult & Plumage & Male & Primary notch & Light & None & $\mathrm{Y}$ & $\begin{array}{l}\text { Right: P 10, P9, S5; } \\
\text { Left: P10, P9, S5 }\end{array}$ & $\mathrm{Y}$ & $\begin{array}{l}\text { Right: R6, R5; } \\
\text { Left: R5 }\end{array}$ & savana & $\begin{array}{l}\text { Primary notch on } \\
\text { P8 }\end{array}$ \\
\hline $2661-39657$ & $7 / 22$ & 1 & 2 & Adult & Plumage & Male & Primary notch & Light & Light & $\mathrm{Y}$ & $\begin{array}{l}\text { Right: P10, P9, S5; } \\
\text { Left: P10, P9, P8, S5 }\end{array}$ & $\mathrm{Y}$ & $\begin{array}{l}\text { R6, R5 } \\
\text { (symmetrical) }\end{array}$ & monachus & $\begin{array}{l}\text { Primary notch } \\
\text { lacking on P8 }\end{array}$ \\
\hline $2661-39658$ & $7 / 22$ & 2 & 2 & Adult & Plumage & Female & No primary notch & Light & Light & $\mathrm{N}$ & & $\mathrm{N}$ & & savana & Back coloration \\
\hline 2661-39659 & $7 / 22$ & 2 & 2 & Juvenile & $\begin{array}{l}\text { Brown } \\
\text { plumage }\end{array}$ & Unknown & $\begin{array}{l}\text { No distinguishing } \\
\text { characters }\end{array}$ & Medium & Light & $\mathrm{N}$ & & $\mathrm{N}$ & & monachus & Back coloration \\
\hline $2661-39663$ & $7 / 22$ & 2 & 3 & Adult & Plumage & Female & No primary notch & Indication & None & $\mathrm{N}$ & & $\mathrm{Y}$ & $\begin{array}{l}\text { R6 } \\
\text { (symmetrical) }\end{array}$ & savana & Back coloration \\
\hline 2661-39664 & $7 / 22$ & 2 & 1 & Adult & Plumage & Male & Primary notch & Medium & Light & $\mathrm{Y}$ & $\begin{array}{l}\text { Right: P10, P9, S5, S6; } \\
\text { Left: P10, P9, S5, S6 }\end{array}$ & $\mathrm{Y}$ & $\begin{array}{l}\text { R6, R5 } \\
\text { (symmetrical) }\end{array}$ & savana & $\begin{array}{l}\text { Primary notch on } \\
\text { P8 }\end{array}$ \\
\hline $2661-39667$ & $7 / 22$ & 1 & 1 & $\begin{array}{l}\text { Juvenile } \\
\end{array}$ & $\begin{array}{l}\text { Brown } \\
\text { plumage }\end{array}$ & Male & Primary notch & Medium & Light & $\mathrm{Y}$ & $\begin{array}{l}\text { P10, S5 } \\
\text { (symmetrical) }\end{array}$ & $\mathrm{Y}$ & $\begin{array}{l}\text { Right: R6, R5, R3, } \\
\text { R2; } \\
\text { Left: R6, R5 }\end{array}$ & savana & $\begin{array}{l}\text { Primary notch on } \\
\text { P8 }\end{array}$ \\
\hline $2661-39670$ & $7 / 26$ & 3 & 3 & Adult & Plumage & Female & No primary notch & None & Light & $\mathrm{N}$ & & $\mathrm{N}$ & & savana & Back coloration \\
\hline $2661-39674$ & $7 / 26$ & 1 & 2 & Adult & Plumage & Male & Primary notch & None & Medium & $\mathrm{N}$ & & $\mathrm{N}$ & & savana & $\begin{array}{l}\text { Primary notch on } \\
\text { P8 }\end{array}$ \\
\hline $2661-39675$ & $7 / 26$ & 1 & 1 & Juvenile & $\begin{array}{l}\text { Brown } \\
\text { plumage }\end{array}$ & Unknown & $\begin{array}{l}\text { No distinguishing } \\
\text { characters }\end{array}$ & Light & Light & $\mathrm{N}$ & & $\mathrm{N}$ & & savana & Back coloration \\
\hline $2661-39680$ & $7 / 26$ & 2 & 2 & Adult & Plumage & Male & $\begin{array}{l}\text { Primary notch } \\
\end{array}$ & Medium & Medium & $\mathrm{Y}$ & $\begin{array}{l}\text { Right: P7, P6, S3; } \\
\text { Left: P7, S3 }\end{array}$ & $\mathrm{Y}$ & $\begin{array}{l}\text { Right: R6, R3, R2; } \\
\text { Left: R6, R5, R2, } \\
\text { R1 }\end{array}$ & monachus & Back coloration \\
\hline 2661-39694 & $7 / 30$ & 1 & 2 & Adult & Plumage & Female & No primary notch & Light & Indication & $\mathrm{N}$ & & $\mathrm{N}$ & & savana & Back coloration \\
\hline $2661-39702$ & $7 / 30$ & 1 & 1 & Adult & Plumage & Female & No primary notch & Light & None & $\mathrm{N}$ & & $\mathrm{N}$ & & savana & Back coloration \\
\hline $2661-39709$ & $7 / 30$ & 1 & 1 & Adult & Plumage & Male & Primary notch & Light & Indication & $\mathrm{Y}$ & $\begin{array}{l}\text { Right: P10, P9, P8, S5, S6; } \\
\text { Left: P10, P9, P8, S4, S5, } \\
\text { S6, T1 }\end{array}$ & $\mathrm{Y}$ & $\begin{array}{l}\text { Right: R6, R5; } \\
\text { Left: R5, R4, R3 }\end{array}$ & monachus & $\begin{array}{l}\text { Primary notch } \\
\text { lacking on P8; } \\
\text { back coloration }\end{array}$ \\
\hline $2661-39710$ & $7 / 30$ & 2 & 3 & Adult & Plumage & Female & No primary notch & Medium & Light & $\mathrm{Y}$ & $\begin{array}{l}\text { Right: P8, S3; } \\
\text { Left: P8, S2 }\end{array}$ & $\mathrm{Y}$ & $\begin{array}{l}\text { Right: R6, R2, R1; } \\
\text { Left: R6, R4, R1 }\end{array}$ & monachus & Back coloration \\
\hline $2661-39711$ & $7 / 30$ & 3 & 3 & Adult & Plumage & Female & No primary notch & Indication & None & $\mathrm{Y}$ & P10 (symmetrical) & $\mathrm{Y}$ & $\begin{array}{l}\text { R6 } \\
\text { (symmetrical) }\end{array}$ & savana & Back coloration \\
\hline $2661-39717$ & $7 / 30$ & 2 & 1 & Adult & Plumage & Male & Primary notch & Medium & Medium & $\mathrm{Y}$ & $\begin{array}{l}\text { Right: P6, S1, T2; } \\
\text { Left: P6, P5, S1, T2 }\end{array}$ & $\mathrm{N}$ & & savana & $\begin{array}{l}\text { Primary notch on } \\
\text { P8, back } \\
\text { coloration }\end{array}$ \\
\hline
\end{tabular}


Table A1.2. Stable nitrogen isotope values of $T$. savana feathers.

\begin{tabular}{|c|c|c|c|c|}
\hline Individual & Subspecies & P1 & S6 & R3 \\
\hline $2661-39624$ & monachus & 8.05 & 8.86 & 8.63 \\
\hline $2661-39627$ & savana & 9.18 & 8.34 & 8.29 \\
\hline $2661-39628$ & savana & 9.86 & 9.16 & 9.56 \\
\hline $2661-39629$ & savana & 10.2 & 7.27 & 9.87 \\
\hline $2661-39630$ & savana & 9.26 & 8.06 & 7.75 \\
\hline $2661-39635$ & savana & 12.35 & 10.69 & 11.06 \\
\hline $2661-39639$ & savana & 9.72 & 7.79 & 8.38 \\
\hline $2661-39645$ & savana & 8.78 & 9.15 & 8.97 \\
\hline 2661-39646 & savana & 10.96 & 10.51 & 9.85 \\
\hline $2661-39648$ & savana & 9.69 & 7.47 & 7.18 \\
\hline $2661-39653$ & savana & 9.27 & 8.46 & 9.28 \\
\hline $2661-39657$ & monachus & 7.97 & 10.02 & 10.06 \\
\hline $2661-39658$ & savana & 10.64 & 8.52 & 8.31 \\
\hline $2661-39659$ & monachus & 7.7 & 7.72 & 7.57 \\
\hline $2661-39663$ & savana & 9.84 & 9.61 & 8.57 \\
\hline $2661-39664$ & savana & 9.06 & & 10.25 \\
\hline $2661-39667$ & savana & 8.86 & 9.64 & 9.15 \\
\hline $2661-39670$ & savana & 10.98 & 9.12 & 9.62 \\
\hline $2661-39674$ & savana & 12.15 & 8.31 & 9.4 \\
\hline $2661-39675$ & savana & 9.23 & 9.12 & 8.73 \\
\hline 2661-39680 & monachus & 9.07 & 8.83 & 8.57 \\
\hline 2661-39694 & savana & 12.79 & 9.13 & 8.92 \\
\hline $2661-39702$ & savana & 9.33 & 7.54 & 7.52 \\
\hline $2661-39709$ & monachus & 8.59 & 9.73 & \\
\hline $2661-39710$ & monachus & & & 9.01 \\
\hline $2661-39711$ & savana & 8.22 & 9.33 & 8.66 \\
\hline $2661-39717$ & savana & 8.13 & 7.62 & 9.92 \\
\hline
\end{tabular}


T. s. savana (migratory)
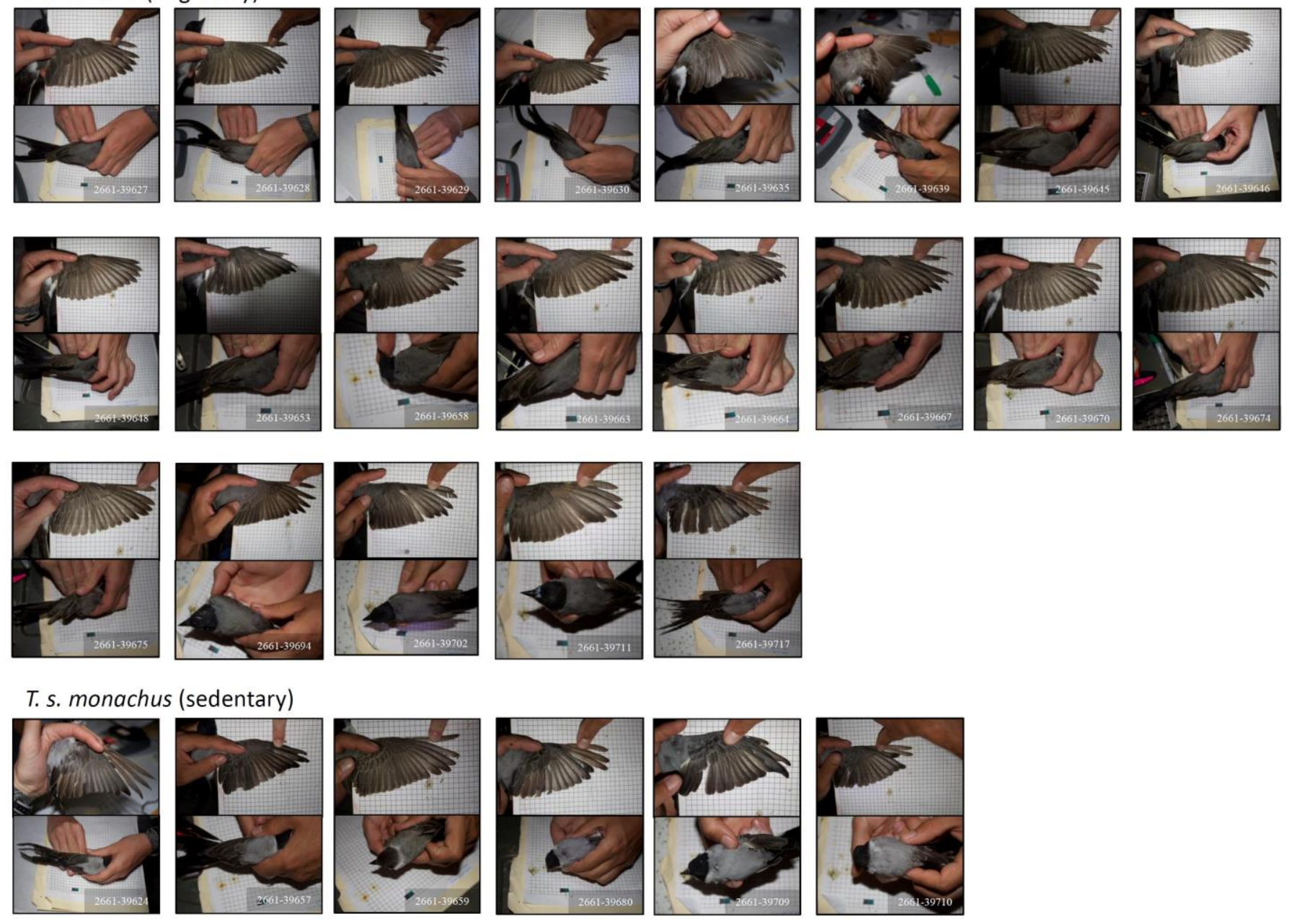

Figure A1.1. Wing and back photos of $T$. savana individuals used to verify age, sex and subspecies in this study. 
Appendix 2

$\mathrm{R}$ code for MacPherson et al. Wilson Journal

\#Analyzing Stable Nitrogen Isotope Data for isotope paper

\#Last updated November 22nd, 2020

$\operatorname{rm}(\operatorname{list}=\operatorname{ls}())$

\#bring in data file

library $(\operatorname{readxl})$

Tyrannus_isotope_data_for_aov <-read_excel(" /Downloads/Tyrannus_isotope_data_for_aov (1).xlsx")

View(Tyrannus_isotope_data_for_aov)

\#Rename data

AOV_isotopes <-Tyrannus_isotope_data_for_aov

\#Check if models that include sex explain more of the variation in isotope results (repeat for each feather: P1, S6, R3)

$\operatorname{lm} 1<-\operatorname{lm}($ N_P1 subspecies, data=AOV_isotopes $)$

$\operatorname{lm} 2<-\operatorname{lm}\left(\mathrm{N} \_\mathrm{P} 1 \sim \operatorname{subspecies} * \operatorname{Sex}\right.$, data=AOV_isotopes $)$

$\mathrm{AIC}(\operatorname{lm} 1, \operatorname{lm} 2)$

\# df AIC

$\# 1 \mathrm{~m} 1$

$\# \operatorname{lm} 2$

\#Check if models that include age explain more of the variation in isotope results for each feather

$\operatorname{lm} 1<-\operatorname{lm}\left(\mathrm{N} \_\mathrm{R} 3 \sim\right.$ subspecies, data=AOV_isotopes $)$ 
$\operatorname{lm} 2<-\operatorname{lm}\left(\mathrm{N} \_\mathrm{R} 3 \sim\right.$ subspecies*Age, data=AOV_isotopes)

\author{
$\operatorname{AIC}(\operatorname{lm} 1, \operatorname{lm} 2)$ \\ \# df AIC \\ \#lm1 \\ \#1m2
}

\#results can be found here:

https://docs.google.com/spreadsheets/d/1DxWMgDnavC8xhzhhQeeENGoEN0wmcODNAs6j_ZNpHQ/edit\#gid=1987429752

\#\#perform ANOVA:

fit_aov<-aov(delta_N Feather*Subspecies+Individual, data=AOV_isotopes)

summary(fit_aov)

\#\#Do Tukey's post hoc test to assess where differences were found.

TukeyHSD(fit_aov) 